\title{
Nutritional support and dietary interventions following esophagectomy: challenges and solutions
}

\author{
Melanie Paul \\ Melanie Baker \\ Robert N Williams \\ David J Bowrey
}

Department of Surgery, Leicester

Royal Infirmary, Leicester, UK
Correspondence: David J Bowrey Department of Surgery, Level 6 Balmoral Building, Leicester Royal Infirmary, LEI 5WW, UK

$\mathrm{Tel}+4401162585247$

Fax +440II6 2586083

Email djb57@le.ac.uk
This article was published in the following Dove Press journal:

Nutrition and Dietary Supplements

9 March 2017

Number of times this article has been viewed

Background and aims: Provision of adequate nutrition after esophagectomy remains a major challenge. The aims of this review were to describe the challenges facing this patient population and to determine the evidence base underpinning current nutritional and dietetic interventions after esophagectomy.

Methods: Medline, Embase and CINAHL databases were searched for English language publications of the period 1990-2016 reporting on the outcome of nutritional or dietetic interventions after esophagectomy or patient-related symptoms.

Results: Four studies demonstrated that early reintroduction of oral fluids was safe and was associated with a shorter hospital stay and ileus duration. One of three studies comparing in-hospital enteral nutrition against usual care showed that enteral feeding was well tolerated and was associated with a shorter hospital stay. Eight studies comparing enteral with parenteral nutrition showed similar surgical complication rates. Enteral feeding was associated with a shorter duration of ileus and lower health care costs. In hospital, all types of enteral access (nasoenteral, jejunostomy) were equivalent in their safety profiles. Cohort studies indicate that technical (tube dysfunction) and feed (diarrhea, distention) problems were common with jejunostomies but are easily managed. The mortality risk associated with jejunostomy in hospital is $0.2 \%$ (reported range $0 \%-1 \%$ ), principally due to small bowel ischemia. There have been no reports of serious jejunostomy complications in patients receiving home feeding. One study demonstrated the advantages of home feeding in weight, muscle and fat preservation. Studies reporting 12 months or more after esophagectomy indicate a high frequency of persistent symptoms, dumping syndrome 15\%-75\% (median 46\%), dysphagia 11\%-38\% (median 27\%), early satiety $40 \%-90 \%$ (median 65\%) and reflux 19\%-61\% (median $29 \%$ ).

Conclusion: Patients should resume oral intake as soon as possible after surgery. In hospital, all forms of enteral access appear to be safe. Out of hospital, the ability to provide home feeding by feeding jejunostomy is likely where meaningful nutritional improvements can be made. Improving nutrition and related quality of life in the early months might improve the long-term outcome.

Keywords: esophagectomy, enteral nutrition, nutrition, nutritional status, weight

\section{Introduction}

Approximately one-third of patients with esophageal cancer will undergo surgical resection (esophagectomy). ${ }^{1}$ For many patients, surgery will form part of multimodal therapy that also includes chemotherapy and radiotherapy. ${ }^{1}$ As a result, the patient treatment journey is protracted, taking up to 6 months to complete. ${ }^{1}$ Nutritional considerations in these patients represent one of the greatest contributors to quality of life. ${ }^{2-4}$ Achieving adequate nutritional intake is a cause for concern at all points in the patient pathway. 
Prior to diagnosis, there may be a physical inability to achieve adequate caloric intake because of dysphagia. After surgery, in the immediate postoperative period, most centers restrict oral intake. After discharge from the hospital, nutritional intake remains poor because of the physical effects of the surgery itself, which include early satiety associated with a reduced gastric volume, altered appetite, taste and smell, dumping syndrome and malabsorption. ${ }^{4}$

A recent systematic review of descriptive longitudinal studies indicated that 6 months after surgery, body weight had fallen by $5 \%-12 \%$, compared to baseline preoperative levels. ${ }^{2}$ More than half of the patients experienced an excess of $10 \%$ weight loss. In the small number of studies reporting on outcome beyond the first year, many subjects had failed to return to their preoperative weight. ${ }^{2}$ In an attempt to ameliorate this weight loss, a small number of centers have moved to a policy of selective or routine home supplementary enteral nutrition. ${ }^{5}$

The aim of this review was to systematically review the evidence and describe the nutritional challenges faced by clinicians and patients after esophagectomy, and the outcome of nutritional or dietetic interventions at any time point after surgery.

\section{Materials and methods}

\section{Article selection}

To be eligible, studies needed to report a dietetic or nutritional intervention (enteral, oral or parenteral feeding), nutrition-related symptoms or quality of life in patients who had undergone esophagectomy. Studies were considered at any time point after surgery, so as to allow exploration of temporal trends, if present. Furthermore, studies reporting on the morbidity of jejunostomy feed use were included if the sample numbered 50 participants or greater. Series reporting smaller numbers of participants were excluded on the basis that the frequency of complications may be too small to allow meaningful interpretation of the data. Studies that reported purely quality of life, where it was not possible to extract nutrition-related symptom information, were excluded.

\section{Search strategy}

A database search strategy was formulated using subject headings and keyword search terms combined for "esophagectomy" and "nutrition therapy" or "enteral nutrition" or "parenteral nutrition" or "quality of life". Medline, Embase and CINAHL were systematically searched (Figure 1). Publications were limited to those reported in the English language during the years 1990-2016. The reference lists of identified

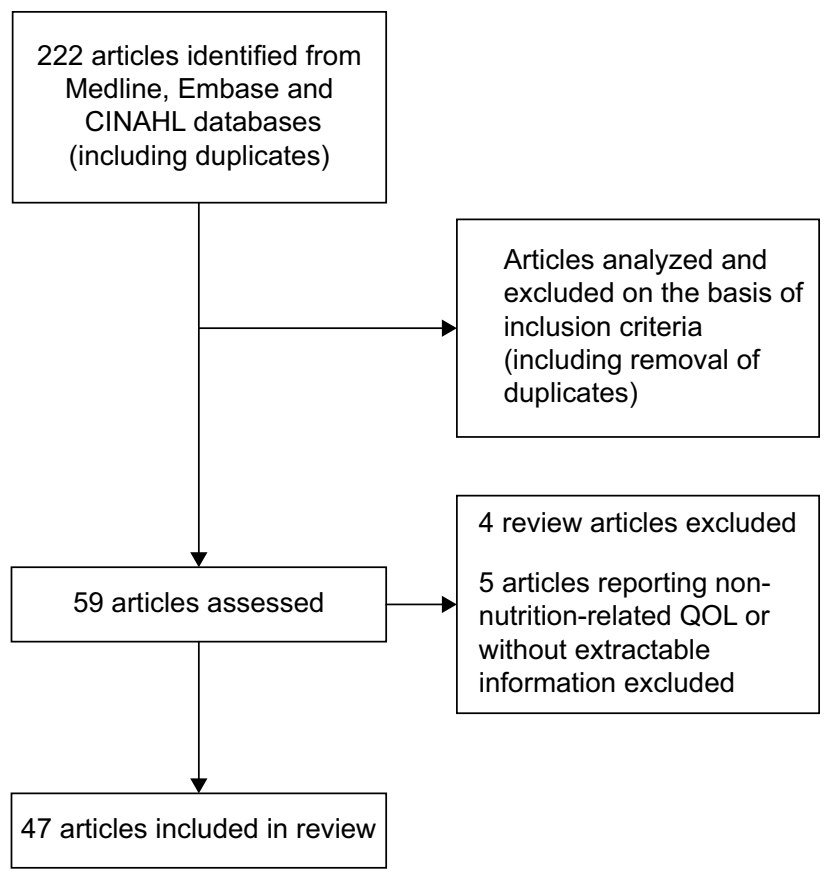

Figure I Summary of search strategy for systematic review. Abbreviation: QOL, quality of life.

articles and other key review publications were additionally hand searched. MP and DJB independently reviewed the process and inclusion of eligible papers.

\section{Assessment of quality: risk of bias}

Risk of bias was assessed using the Cochrane collaborative guidance for randomized controlled trials with additional guidance from the Newcastle-Ottawa Scale for assessing nonrandomized studies. ${ }^{6,7}$

\section{Data extraction}

Data were extracted from the included studies by MP and then independently validated by all coauthors. A consensus was reached in areas of controversy.

\section{Results}

The database search identified 222 studies of potential interest (including duplication). Three articles were identified from the bibliographies of retrieved articles. Eligibility criteria were generally well reported, but a number of studies included patients who underwent pancreatectomy and gastrectomy as well as esophagectomy. ${ }^{8-10}$ The length of postoperative follow-up ranged from the immediate postoperative phase to 38 years. ${ }^{11}$ Only two studies were designed on a multicenter basis. ${ }^{12,13}$

After full study review, 47 articles met the inclusion criteria and formed the basis of this review (Table 1). These fell into five categories: two-arm studies comparing the outcome 


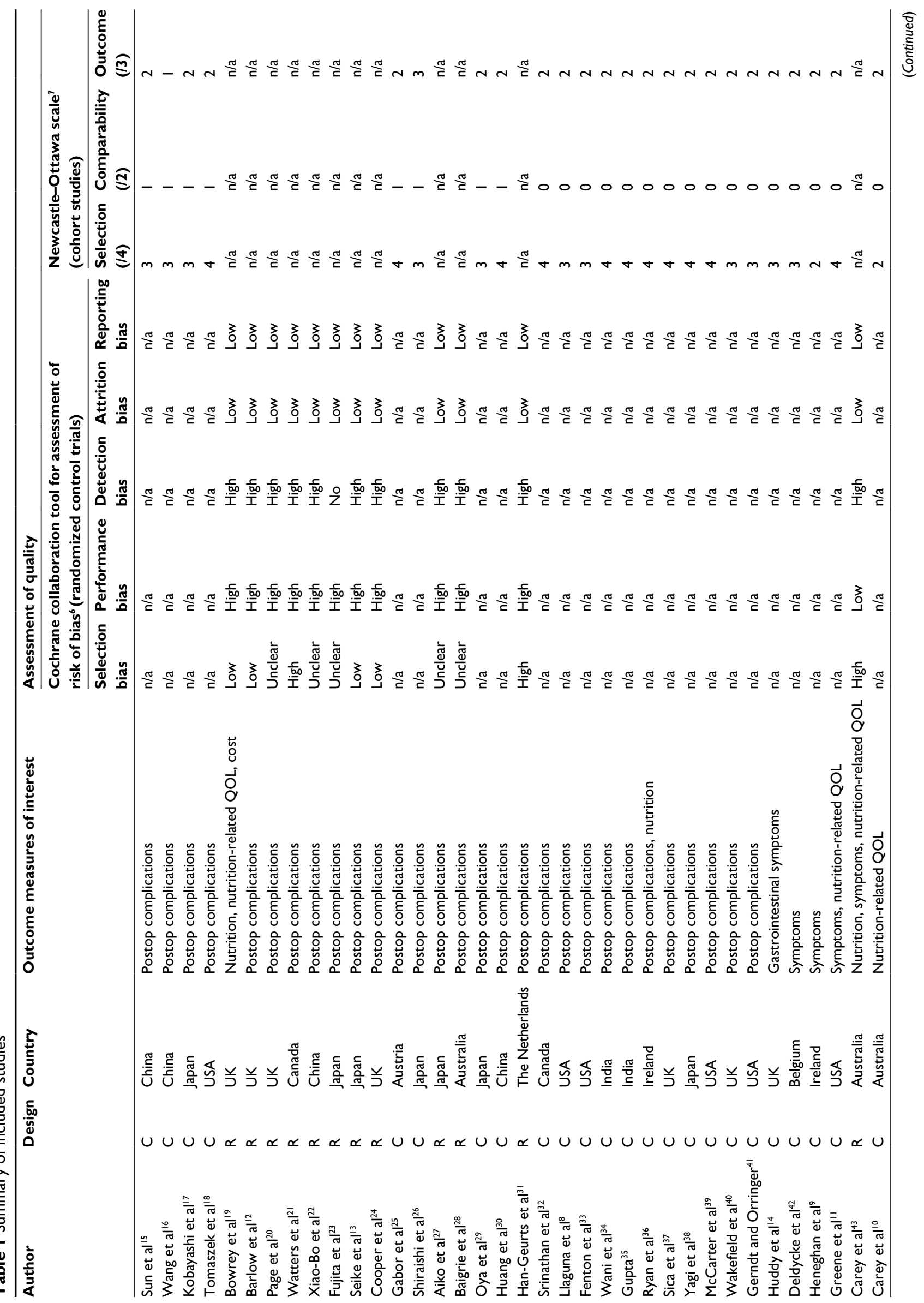




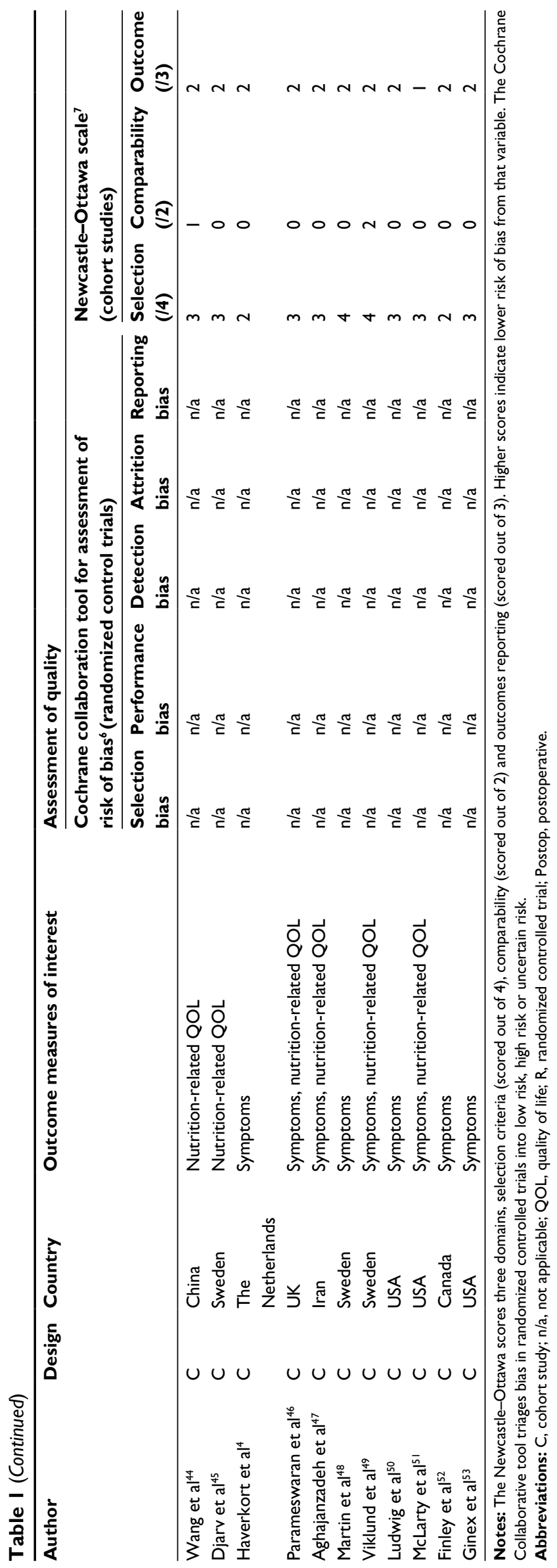

of interventions (12 studies), two-arm studies comparing timing of reintroduction of oral fluids after surgery (4 studies), two-arm studies comparing feeding access routes (3 studies), single-arm studies reporting the outcome (usually safety) of feeding access or regimen (13 studies) and single-arm studies reporting patient symptom prevalence (14 studies). One study reported the outcome of enzyme supplementation. ${ }^{14}$ Four review articles were excluded from the analysis.

\section{Quality of studies}

Table 1 gives an overview of the quality of the studies. No study was considered to be completely free of bias. The limitations to the randomized studies largely related to performance and detection bias due to failure of blinding of patient and/or researcher to the arm of allocation. These reports were considered good in their reporting of patient follow-up and presenting all measured outcome information. The cohort studies were considered good in their reporting of representative cohorts with the condition of interest. The major sources of bias in these studies arise from their limited reporting of comparator populations.

\section{Early challenges Interruption of oral diet \\ Because of concerns about anastomotic healing, oral feeding is delayed in the first days after esophagectomy, typically, the first 5-7 days. Strategies to deal with this first week have included 1) administration of intravenous fluids only with no nutrition, 2) administration of parenteral nutrition or 3) provision of jejunal feeding by nasojejunal or jejunostomy tube coupled with intravenous fluids. The approach taken to provision of nutrition in these early days varies between centers. This was highlighted in the UK National Oesophago- gastric Cancer Audit. ${ }^{1}$ Some centers used feeding adjuncts (generally feeding jejunostomy) for all patients, some used feeding adjuncts on a selective basis in patients considered to be at high risk of nutritional failure, while other centers used no feeding adjunct at all.}

\section{Timing of reintroduction of oral diet}

Table 2 summarizes the four cohort studies that evaluated optimal timing of reestablishing oral or enteral fluid intake. ${ }^{15-18}$ The earlier reintroduction of oral or enteral fluid had no deleterious effects on clinical outcome, specifically anastomotic leak. Rather, the earlier reintroduction of oral or enteral fluids was associated with a reduced length of hospital stay, with a combined mean length of hospital stay of $19 \pm 5 \mathrm{vs}$ $25 \pm 18$ days (mean \pm standard deviation [SD]) ${ }^{15-17}$ The overall 
Table 2 Summary of studies comparing the timing of reintroduction of oral/enteral intake

\begin{tabular}{|c|c|c|c|c|c|}
\hline Study & Design & Sample & Early feeding regimen & Late feeding regimen & Principal study findings \\
\hline Sun et $\mathrm{al}^{15}$ & C & 135 & $\begin{array}{l}\text { Oral fluid diet at will from } \\
\text { postoperative day I (after } \\
\text { negative gastric emptying } \\
\text { test on the same day); } \\
\mathrm{n}=68\end{array}$ & $\begin{array}{l}\text { Enteral feeding by jejunostomy } \\
\text { or nasoenteral tube; } \\
\text { commencement of oral liquid } \\
\text { diet on postoperative day } 7 \text {; } \\
n=65\end{array}$ & $\begin{array}{l}\text { Reduced length of ileus and length of } \\
\text { hospital stay in early feeding group } \\
\text { No difference in overall complications } \\
\text { between two groups }\end{array}$ \\
\hline Wang et al ${ }^{16}$ & C & 208 & $\begin{array}{l}\text { Two early enteral nutrition } \\
\text { groups; } \\
\text { Group I- feed started } \\
\text { within } 48 \mathrm{~h}(\mathrm{n}=10 \mathrm{I}) \text {, } \\
\text { Group } 2 \text { feed started } \\
48-72 \mathrm{~h}(\mathrm{n}=87) ; \text { by } \\
\text { nasojejunal tube }\end{array}$ & $\begin{array}{l}\text { Group 3: start of enteral } \\
\text { nutrition }>72 \text { h; by nasojejunal } \\
\text { tube }(n=20)\end{array}$ & $\begin{array}{l}\text { Reduced length of ileus and length of } \\
\text { hospital stay in Group I } \\
\text { Higher rate of pneumonia in delayed } \\
\text { feeding group (Group 3) compared to } \\
\text { Group I } \\
\text { No difference in anastomotic leak rate } \\
\text { between groups }\end{array}$ \\
\hline Kobayash $^{17}$ & C & 103 & $\begin{array}{l}\text { Enteral nutrition started } \\
\text { within } 3 \text { days of surgery by } \\
\text { jejunostomy; } n=43\end{array}$ & $\begin{array}{l}\text { Enteral nutrition started } \\
\text { after postoperative day } 3 \text { by } \\
\text { jejunostomy; } n=6 \mathrm{I}\end{array}$ & $\begin{array}{l}\text { Reduced length of ileus and length of } \\
\text { hospital stay in early feeding group } \\
\text { No difference in postoperative } \\
\text { complications between groups }\end{array}$ \\
\hline Tomaszek et a $\left.\right|^{18}$ & C & 386 & $\begin{array}{l}\text { Oral diet commenced at } \\
\text { postoperative day 5-7 } \\
\text { following negative contrast } \\
\text { swallow study (conventional } \\
\text { pathway); n=l } 10\end{array}$ & $\begin{array}{l}\text { Feeding by jejunostomy only } \\
\text { until postoperative week } 4 \\
\text { (alternative pathway); } n=276\end{array}$ & $\begin{array}{l}\text { Reduced length of hospital stay in early } \\
\text { feeding group } \\
\text { Radiologic anastomotic leak rate lower in } \\
\text { late feeding group }\end{array}$ \\
\hline
\end{tabular}

Abbreviation: C, cohort study.

complication rates were similar between the two groups ( $40 \%$ vs $45 \%)$. The three studies that measured duration of postoperative ileus time found that earlier reintroduction of oral or enteral intake reduced duration of ileus from a mean of 7 days (SD 2) to a mean of 5 days (SD 1). ${ }^{15-17}$ It should be highlighted that in common with most studies, resumption of eating did not occur until the seventh day, irrespective of when fluids were permitted.

\section{Provision and value of postoperative nutritional support}

There have been three studies (Table 3 ) comparing in hospital enteral nutrition against a control arm of intravenous fluid only. ${ }^{12,20,21}$ These showed that enteral feeding was generally well tolerated and safe. A study by Barlow et $a{ }^{12}$ was the only one that demonstrated a significant difference in the length of hospital stay; median length of hospital stay was 16 days (interquartile range 9) vs 19 days (interquartile range 11) in favor of enteral feeding compared to usual care $(p=0.023)$. The other two studies showed no advantage for enteral feeding over intravenous fluids alone. It may simply be that the overall contribution from enteral feeding in hospital is too small to confer identifiable benefit. Typically, enteral feeding regimens are stepped up, with infusion rates starting off slowly, typically $20 \mathrm{~mL} / \mathrm{h}$, building up to a full feed rate of $75-100 \mathrm{~mL} / \mathrm{h}$ during the course of the first week. We have previously demonstrated that even with such a planned regimen of jejunostomy feeding in hospital, the contribution from this was only $50 \%$ of estimated daily needs. Patients took on average 8 days to achieve full jejunal feeding rate..$^{54}$

It should be borne in mind that up to $40 \%$ of patients undergoing esophagectomy will experience a postoperative complication. ${ }^{1}$ Provision of nutrition in this group of patients is a challenge and, without enteral access, relies upon provision of parenteral nutrition for a potentially prolonged period of time.

\section{Route of feeding access}

\section{Enteral vs parenteral nutrition}

The principal routes of nutritional support employed include enteral (nasojejunal, jejunostomy) and parenteral. There have been eight studies comparing the outcome of enteral vs parenteral nutrition (Table 4). ${ }^{13,22-28}$ Seven of these looked at the rate of individual complications between the two groups as either a primary or secondary end point. . $^{13,22,23,25-28}$ The rates of surgical complications were similar in both groups; specifically, the rates of anastomotic leak (enteral: median $10 \%$, range $0 \%-48 \%$; parenteral: median $19 \%$, range $0 \%-52 \%$ ), wound infections (enteral: median $6 \%$, range $2 \%-16 \%$; parenteral: median $7 \%$, range $0 \%-15 \%$ ) and pneumonia/chest infections (enteral: median $13 \%$, range $0 \%-53 \%$; parenteral: median $11 \%$, range $0 \%-62 \%$ ) were comparable in both groups. Overall, these studies concluded that enteral feeding was a safe, acceptable alternative to parenteral nutrition, and that 
Table 3 Summary of studies comparing enteral feeding with usual care

\begin{tabular}{|c|c|c|c|c|c|c|c|c|}
\hline Study & Design & Sample & $\begin{array}{l}\text { Enteral feeding } \\
\text { regimen }\end{array}$ & $\begin{array}{l}\text { Length of } \\
\text { hospital stay } \\
\text { in days } \\
\text { (mean } \pm S D)\end{array}$ & $\begin{array}{l}\text { Usual care } \\
\text { regimen }\end{array}$ & $\begin{array}{l}\text { Length of } \\
\text { hospital } \\
\text { stay in days } \\
\text { (mean } \pm S D \text { ) }\end{array}$ & $\begin{array}{l}\text { Duration } \\
\text { of follow- } \\
\text { up }\end{array}$ & $\begin{array}{l}\text { Principal study } \\
\text { findings }\end{array}$ \\
\hline Bowrey et $a^{5, a}$ & $\mathrm{R}$ & 54 & $\begin{array}{l}\text { Jejunostomy: } \\
6 \text { weeks of } \\
\text { overnight feeding } \\
\text { at home to } \\
\text { provide at least } \\
50 \% \text { of calorific } \\
\text { requirements; } \\
n=20\end{array}$ & $19 \pm 7$ & $\begin{array}{l}\text { No home } \\
\text { feeding unless } \\
\text { clinically } \\
\text { indicated; } n=2 \text { I }\end{array}$ & $16 \pm 7$ & 26 weeks & $\begin{array}{l}\text { High levels of compliance } \\
\text { with patient/carer } \\
\text { jejunostomy tube care } \\
\text { and feeding } \\
\text { No difference in mean } \\
\text { cost between two arms } \\
\text { Control group lost on } \\
\text { average } 4 \mathrm{~kg} \text { more than } \\
\text { intervention group at } \\
6 \text { weeks, with differences } \\
\text { maintained at } 3 \text { and } \\
6 \text { months }\end{array}$ \\
\hline Barlow et al $\left.\right|^{12, b}$ & $\mathrm{R}$ & 121 & $\begin{array}{l}\text { Jejunostomy: } \\
20-80 \mathrm{~mL} / \mathrm{h} \text { of feed } \\
\text { commenced within } \\
12 \mathrm{~h} \text { of surgery } \\
\text { until hospital } \\
\text { discharge; } \mathrm{n}=64\end{array}$ & 16* (IQR 9) & $\begin{array}{l}\text { Intravenous } \\
\text { fluids only } \\
\text { until oral diet } \\
\text { recommenced } \\
\text { (day 7-10); } \\
\mathrm{n}=57\end{array}$ & I9* (IQR II) & 12 weeks & $\begin{array}{l}\text { Reduced rate of wound/ } \\
\text { chest infections and } \\
\text { reduced length of } \\
\text { hospital stay in enterally } \\
\text { fed group }\end{array}$ \\
\hline Page et $\mathrm{al}^{20}$ & $\mathrm{R}$ & 40 & $\begin{array}{l}\text { Nasojejunal: } \\
25-100 \mathrm{~mL} / \mathrm{h} \\
\text { of feed until oral } \\
\text { fluid intake re- } \\
\text { established; } \mathrm{n}=20\end{array}$ & $14 \pm 5$ & $\begin{array}{l}\text { Intravenous } \\
\text { fluids until } \\
\text { oral diet } \\
\text { recommenced } \\
\text { (day 7-10); } \\
\mathrm{n}=20\end{array}$ & $13 \pm 5$ & I week & $\begin{array}{l}\text { Feed safe and well } \\
\text { tolerated } \\
\text { No difference } \\
\text { in postoperative } \\
\text { complications between } \\
\text { groups }\end{array}$ \\
\hline Watters et $\mathrm{al}^{21}$ & $\mathrm{R}$ & 28 & $\begin{array}{l}\text { Jejunostomy: } \\
20-80 \mathrm{~mL} / \mathrm{h} \text { of } \\
\text { feed until hospital } \\
\text { discharge; } n=13\end{array}$ & $17 \pm 9$ & $\begin{array}{l}\text { Intravenous } \\
\text { fluids until } \\
\text { oral diet } \\
\text { recommenced } \\
\text { (day 6); } n=15\end{array}$ & $16 \pm 7$ & I week & $\begin{array}{l}\text { No difference in hand } \\
\text { grip strength, fatigue or } \\
\text { vigor between groups } \\
\text { Reduced FEV, and FVC } \\
\text { in enterally fed group }\end{array}$ \\
\hline
\end{tabular}

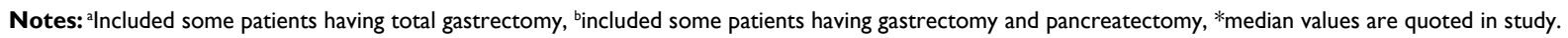
Abbreviations: $\mathrm{FEV}_{\mathrm{I}}$, forced expiratory volume in I second; FVC, forced vital capacity; IQR, interquartile range; R, randomized controlled trial; SD, standard deviation.

enteral feeding was linked to a shorter duration of ileus and lower feed-associated costs. Parenteral feeding is no longer used in patients with an intact gastrointestinal system. Its place is solely in patients with loss of gastrointestinal continuity (prolonged ileus, postoperative complications). This is largely due to the risks of venous access complications and the much higher costs associated with parenteral over enteral nutrition. ${ }^{26}$

The majority of centers that administer adjunctive feeding use either nasojejunal or jejunal approaches. The limited evidence available indicates that for in-hospital use, the two are equivalent (Table 5). Although the risk of serious complications is lower with nasojejunal feeding, a robust approach is required because of frequent tube displacements or occlusions. ${ }^{29-31}$ Furthermore, it is not a common practice to discharge patients from the hospital with nasojejunal catheters in situ, limiting their longer term use in the community.

\section{Access problems}

Table 6 summarizes the clinical outcomes for patients with feeding jejunostomies in studies reporting on 50 patients or greater. ${ }^{8,30-41}$ Both technical and feed-related problems are quite common. The former can usually be managed by repositioning or replacing the tube, and the latter by adjusting the rate or type of feed. Tube dysfunction (occlusion or dislocation of the tube) has been reported in $0.5 \%-17 \%$ of patients (median 7\%) and tube site infection in $0.5 \%-16 \%$ (median 4.5\%). Gastrointestinal side effects were observed frequently, notably diarrhea and distension that were reported in $6 \%-24 \%$ (median $9 \%$ ) and $3 \%-18 \%$ (median $4 \%$ ) of patients, respectively. ${ }^{8,30-41}$ The frequencies of gastrointestinal side effects shown in Table 6 are those necessitating a change in the feeding regimen (reduced infusion rate, change in type of feed, cessation of feed).

There have been four recorded deaths that were acknowledged to be directly attributable to a jejunostomy tube 


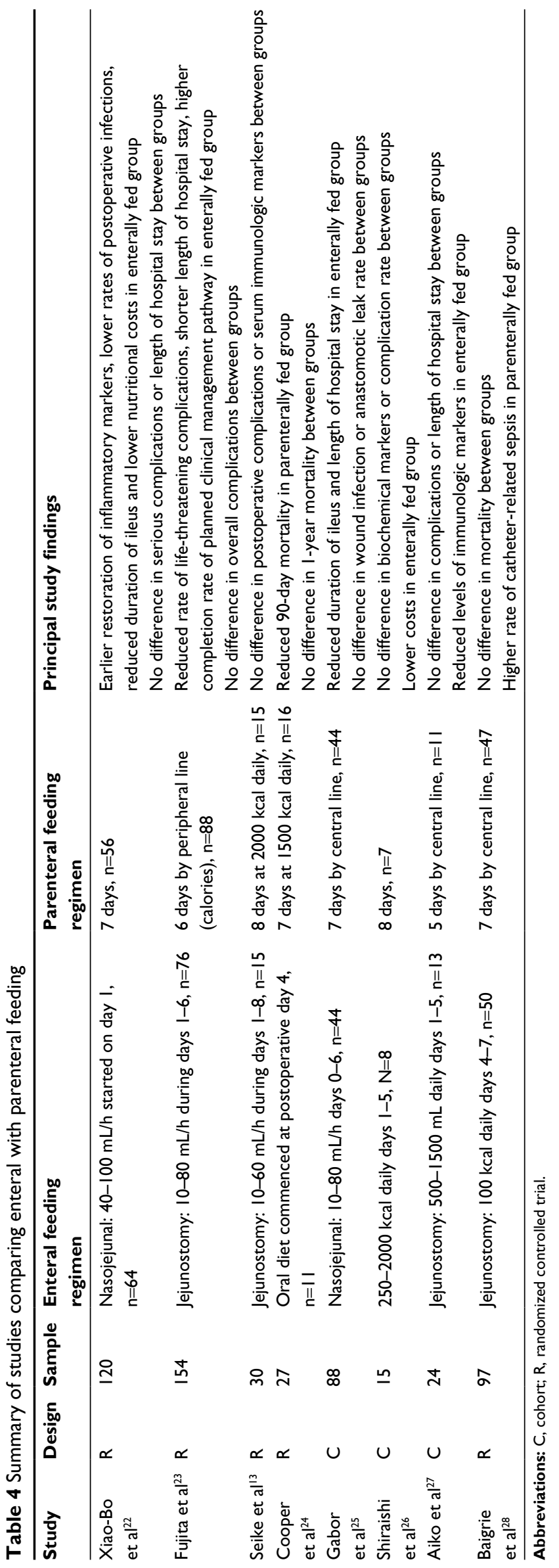

catheter $(\mathrm{N}=2510)$, indicating an average mortality rate of $0.2 \%$ overall (range $0 \%-1 \%$ ). ${ }^{13,32,36}$ Twenty-three patients were reported to require operative intervention for complications attributable to the jejunostomy tube (mean $6 \%$, range $0 \%-20 \%)^{8,31-34,36,37,40}$ The complications mandating re-laparotomy comprised small bowel ischemia or perforation (5 patients), small bowel obstruction (5 patients) and tube dislocation/blockage (12 patients). All of these complications occurred during the index admission for esophagectomy. There have been no reports of serious jejunostomy complications in patients receiving home feeding.

The type of feeding regimens reported were broadly similar, starting with water at a rate of $25 \mathrm{~mL} / \mathrm{h}$ followed by a stepped increase in the rate of enteral feed up to peak infusion rates in the range of $84-110 \mathrm{~mL} / \mathrm{h} \cdot{ }^{37,39,40}$ Where studies reported the type of feed administered, all had used isotonic solutions. It is unclear whether all employed "rest" periods interspersed with the feeding or whether feeding was run continuously for $24 \mathrm{~h}$ daily.

\section{Later challenges}

\section{Nutrition and weight}

The principal challenge after hospital discharge from surgery is the weight loss that ensues. We have previously reviewed this and concluded that at 6 months after surgery, weight loss of $5 \%-12 \%$ was usual, with more than half the patients losing in excess of $10 \%$ of their body weight at 12 months. These observations persisted up to 3 years after surgery. ${ }^{2}$ There is relatively little published on addressing this weight loss after surgery. In a study of 203 patients, Martin and Lagergren ${ }^{55}$ found that $15 \%$ of patients had a preoperative weight loss of $\geq 10 \%$, with $33 \%$ of patients losing $\geq 15 \%$ weight 3 years postesophagectomy. Two randomized controlled trials have reported the use of intensive dietetic monitoring and the use of extended enteral feeding at home. ${ }^{5,43}$ In the first study, Carey et al randomized patients to intensive dietetic follow-up, which comprised telephone or face-to-face follow-up every 2 weeks or usual care. ${ }^{43}$ Intensive monitoring was associated with a nonsignificant improvement in weight, but had no effect on other measures, including global quality of life scores using the European Organization for Research and Treatment of Cancer quality of life questionnaire (EORTC QLQ-C30) tool.

In the second study, we reported on the use of a planned program of home jejunostomy feeding compared to usual nutritional care, after esophagectomy. ${ }^{5}$ In this study, supplementary overnight jejunostomy feeds provided at least $50 \%$ of energy and protein requirements for a minimum of 6 weeks after hospital discharge. Patients were encouraged to eat and drink without restriction, that is, the jejunal feed was not 
Table 5 Studies comparing different routes of enteral access

\begin{tabular}{|c|c|c|c|c|c|}
\hline Study & Design & Sample & Intervention route & $\begin{array}{l}\text { Comparator } \\
\text { route }\end{array}$ & Principal study findings \\
\hline Oya et al ${ }^{29}$ & C & 378 & $\begin{array}{l}\text { Duodenostomy, } \\
n=1 I I\end{array}$ & $\begin{array}{l}\text { Jejunostomy, } \\
n=267\end{array}$ & $\begin{array}{l}\text { Fewer catheter site infections with duodenostomy ( } 1 \% \text { vs } 5 \% \text {, } \\
p=0.08 \text { ) } \\
\text { Reduced length of hospital stay with duodenostomy (mean } \\
15 \text { vs } 37 \text { days, } p<0.001 \text { ) }\end{array}$ \\
\hline Huang et $\mathrm{al}^{30}$ & C & 274 & $\begin{array}{l}\text { Retrosternal route } \\
\text { gastrostomy, } n=|2|\end{array}$ & $\begin{array}{l}\text { Jejunostomy, } \\
n=153\end{array}$ & $\begin{array}{l}\text { Use of gastrostomy associated with lower risk of intestinal } \\
\text { obstruction }(0 \% \text { vs } 7 \%, p=0.003) \text {, catheter-related infection } \\
\text { ( } 2 \% \text { vs } 6 \%, p=0.05) \text { and reduced length of hospital stay } \\
\text { (II vs } 15 \text { days, } p<0.001 \text { ) }\end{array}$ \\
\hline Han-Guerts et $a^{31}$ & $\mathrm{R}$ & 150 & $\begin{array}{l}\text { Nasoduodenal tube, } \\
n=71\end{array}$ & $\begin{array}{l}\text { Jejunostomy, } \\
\mathrm{n}=79\end{array}$ & $\begin{array}{l}\text { No differences in tolerance of enteral feeding ( } 93 \% \text { vs } 89 \% \text { ) or } \\
\text { rates of catheter-related complications ( } 29 \% \text { vs 38\%) between } \\
\text { groups }\end{array}$ \\
\hline
\end{tabular}

Abbreviations: C, cohort; R, randomized controlled trial.

intended to replace oral intake, but was used in addition. Home feeding was shown to have advantages in terms of weight preservation, preservation of muscle and fat stores. The impact of the intervention was further explored in a qualitative study, which interviewed 15 trial participants and 8 family members in an informal carer role. ${ }^{56}$ All participants talked about the challenges of living with a feeding tube, but these existed even if the tube was not used for feeding. Those who used the jejunostomy tube for supplementary feeding described an overwhelming sense that the feed had "done them good". High compliance rates with the feeding regimen were seen.

\section{Postsurgical gastrointestinal symptoms}

Table 7 summarizes the studies reporting on the most common patient symptoms after surgery., ${ }^{4,11,42,44-53}$ These indicate a high prevalence of gastrointestinal symptoms. In studies reporting at 12 months or more, symptoms were seen with the following frequency: dumping syndrome $15 \%-75 \%$ (median 46\%), dysphagia 11\%-38\% (median 27\%), early satiety $40 \%-90 \%$ (median $65 \%$ ) and reflux symptoms 19\%-61\% (median 29\%). Other symptoms reported included odynophagia with a range of $6 \%-37 \%$ ( 2 studies), delayed gastric emptying 37\% (1 study) and malabsorption $73 \%$ (1 study). ${ }^{42,45,47}$

In patients with dysphagia, it is important to exclude anastomotic strictures, which affect up to a third of patients after surgery. In general terms, the more proximal the anastomosis, the greater is the risk of anastomotic stricture; therefore, patients with neck anastomoses after transhiatal or three-stage esophagectomy carry the greatest risk. Other risk factors include the anastomosis diameter, with a smaller diameter conferring a greater risk of stricture..$^{42}$ Anastomotic strictures can be successfully managed by endoscopic dilatation. ${ }^{57}$ Reflux symptoms are the result of surgical removal of lower esophageal sphincter and the formation of an iatrogenic hiatal hernia as part of the esophagectomy procedure. In the author's experience, at least $50 \%$ of patients will require long-term antisecretory medications after esophagectomy. Djarv et $a{ }^{45}$ investigated whether reduced long-term survival correlated with the markers of health-related quality of life assessed 6 months after esophagectomy. The authors found an association between nutrition-related symptoms and subsequent mortality as follows: loss of appetite (hazard ratio $[\mathrm{HR}]=1.69 ; 95 \%$ confidence interval $[\mathrm{CI}]: 1.32-2.14$ ), dysphagia $(\mathrm{HR}=1.69 ; 95 \% \mathrm{CI}: 1.13-2.51)$ and esophageal pain (HR=1.29; 95\% CI: 1.02-1.65).

Heneghan et $\mathrm{al}^{9}$ defined malabsorption by two or more of the following criteria: 1) steatorrhea-specific symptoms by questionnaire; 2 ) $>10 \%$ weight loss compared to preoperative weight; 3) fecal elastase-1 level <200 $\mu \mathrm{g}$ /day; 4) fat-soluble vitamin deficiencies; 5) taking pancreatic enzyme replacement therapy and 6) positive hydrogen breath test indicating small intestinal bacterial overgrowth. They found that $73 \%$ of patients had evidence of malabsorption, an average of 2 years after surgery. ${ }^{9}$ Huddy et al showed that $16 \%$ of patients after esophagectomy had fecal elastase-1 levels $<200 \mu \mathrm{g} /$ day, indicating mild-moderate pancreatic enzyme insufficiency. ${ }^{14}$ Ninety percent of the treated patients reported symptomatic improvement with the use of pancreatic enzyme replacement therapy. ${ }^{14}$

It is also evident from Table 7 that the gastrointestinal symptoms experienced after esophagectomy persist in the longer term. In a prospective study of 218 patients after esophagectomy, Ginex et al ${ }^{53}$ grouped symptoms (gastrointestinal and nongastrointestinal) as follows:

1. Those that had worsened after surgery, but recovered to baseline by 12 months (appetite change, taste change, cough, difficulty sleeping, dry mouth, lack of energy, not looking like self, pain, shortness of breath, weight loss); 


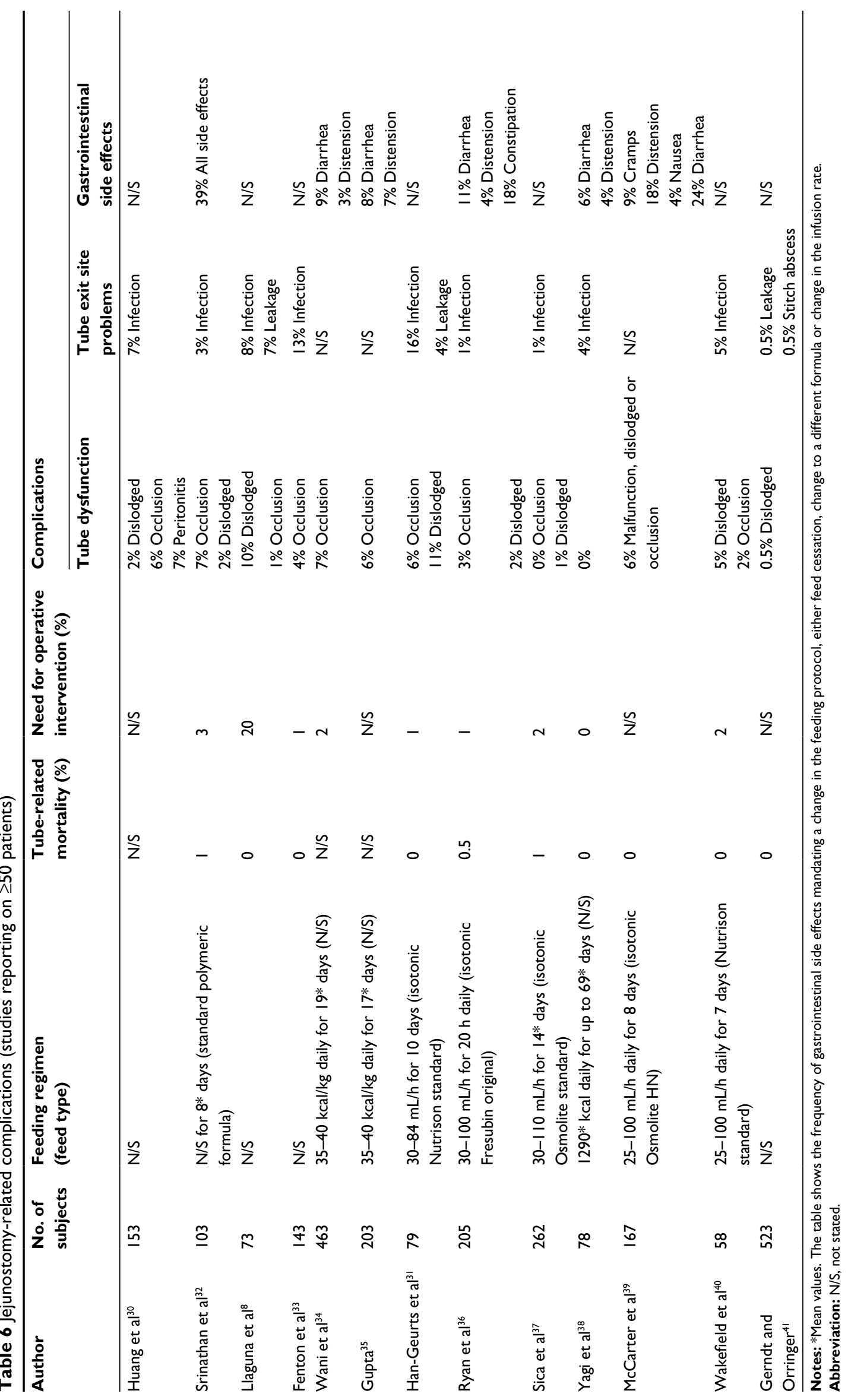




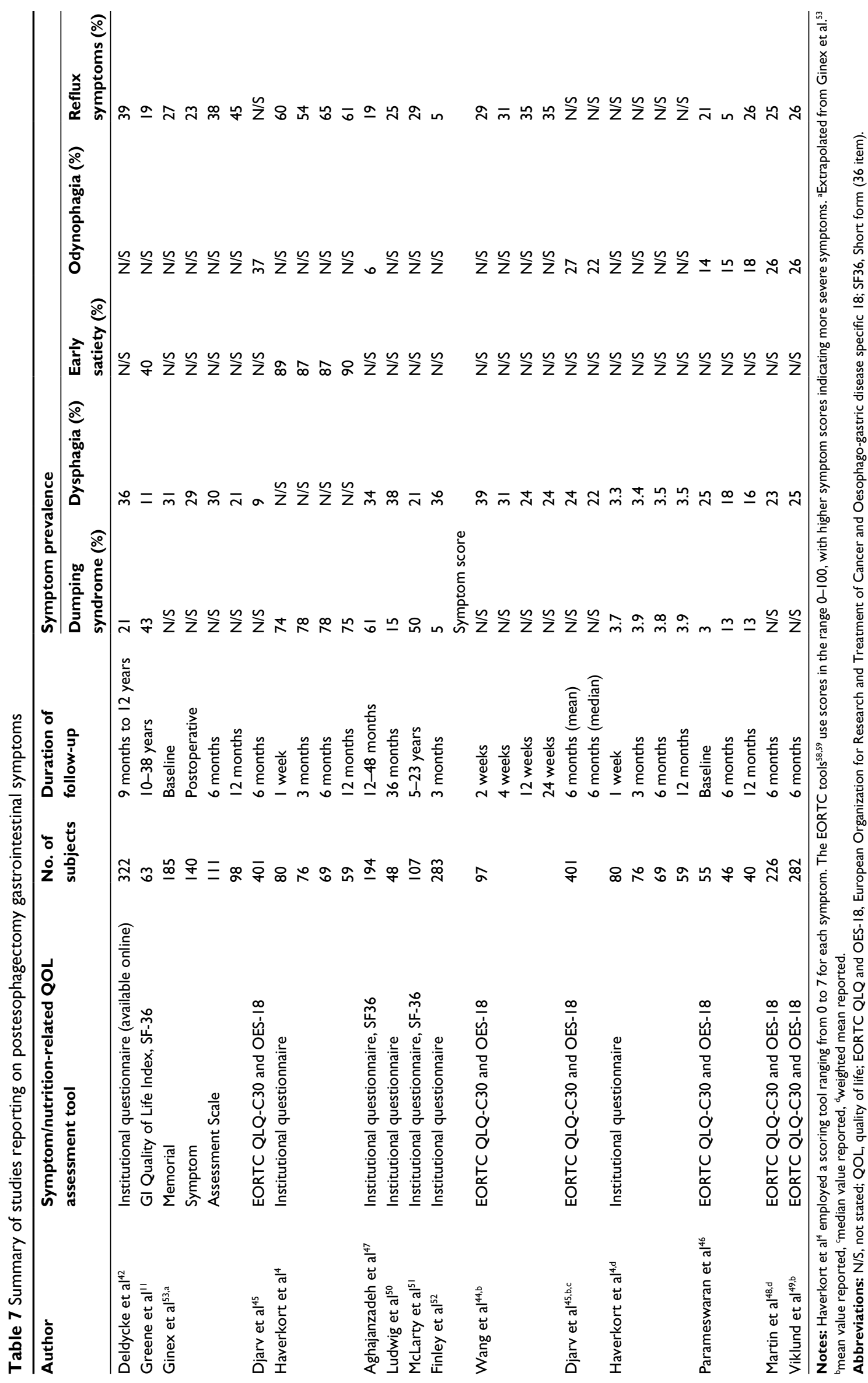


2. Those that had worsened after surgery, but did not recover by 12 months (bloating, diarrhea, drowsiness, early satiety, nausea);

3. Those that had worsened after surgery and further deteriorated at 12 months (reflux) and

4. Those that were unchanged at 12 months after esophagectomy (difficulty concentrating, difficulty swallowing, sexual issues). ${ }^{53}$

Carey et $\mathrm{al}^{10}$ in an interview study reported a period of adjustment to new eating patterns after esophagectomy and how patients developed a "love-hate" relationship with food and how this impacted on their socialization experiences. Patients reported specifically avoiding social situations that involved food to prevent the embarrassment of not being able to eat as much as their peers and, without warning, vomiting if they had overeaten. ${ }^{43}$

\section{Conclusion}

One-third of patients with esophageal cancer will undergo esophagectomy. ${ }^{1}$ Therefore, there is a significant need to appreciate the dietetic and nutritional demands required by this cohort from the time of diagnosis through the treatment journey and beyond. Optimization of nutritional intake in order to minimize weight loss is vital to maintain the physiologic reserve required for surgery.

On the basis of the evidence presented, it is no longer feasible to routinely keep patients without oral intake for at least 7 days postoperatively due to concerns regarding anastomotic leak/damage. Early oral intake within $72 \mathrm{~h}$ of surgery has been shown to be safe. We have recently moved to starting oral fluids the day after surgery. There is little role for parenteral nutrition in the postoperative phase unless there is loss of gastrointestinal continuity or function. In hospital, all forms of enteral access have been shown to be safe. It is the authors' preference to place a feeding jejunostomy and to discharge patients from the hospital with this access in situ for a minimum of 6 weeks. The main benefit of enteral feeding lies in the out-of-hospital setting, where meaningful contributions to calorie and protein requirements can be made. Serious complications of jejunostomy feeding and access are limited to the immediate postresection hospitalization. It is the authors' preference to limit the jejunal feeding rate to $40 \mathrm{~mL} / \mathrm{h}$ for the first $72 \mathrm{~h}$ after surgery or if patients are ventilated or requiring inotropic support. Complications of enteral feeding after discharge are limited to minor tube site problems and gastrointestinal symptoms. The latter can be managed by adjusting the rate or type of feed.
In the longer term, it is evident that many patients suffer from postsurgical symptoms, principally gastrointestinal. These have a deleterious effect on the quality of life and persist years after esophagectomy. The focus of future work should be on the strategies to ameliorate these symptoms.

\section{Author contributions}

All authors contributed to the study design, planning and data extraction. DJ Bowrey, M Paul and M Baker drafted the initial manuscript. RN Williams revised the initial manuscript. All authors have seen and approved the final draft.

\section{Disclosure}

The authors report no conflicts of interest in this work.

\section{References}

1. Royal College of Surgeons of England. National Oesophago-gastric Cancer Audit. 2014. Available from: http://www.augis.org/wp-content/ uploads/2014/05/NOGCA-PROGRESS-Report-2014_Final.V2.pdf. Accessed February 22, 2017.

2. Baker M, Halliday V, Williams RN, Bowrey DJ. A systematic review of the nutritional consequences of esophagectomy. Clin Nutr. 2016;35(5): 987-994.

3. Baldwin C, Spiro A, Ahern R, Emery PW. Oral nutritional interventions in malnourished patients with cancer: a systematic review and metaanalysis. J Natl Cancer Inst. 2012;104(5):371-385.

4. Haverkort EB, Binnekade JM, Busch ORC, van Berge Henegouwen MI, de Haan RJ, Gouma DJ. Presence and persistence of nutrition-related symptoms during the first year following esophagectomy with gastric tube reconstruction in clinically disease-free patients. World J Surg. 2010;34(12):2844-2852.

5. Bowrey DJ, Baker M, Halliday V, Thomas AL, Pulikottil-Jacob R, Smith K. Six weeks of home enteral nutrition versus standard care after esophagectomy or total gastrectomy for cancer: study protocol for a randomized controlled trial. Trials. 2014;15:187.

6. Higgins JPT, Altman DG, Gøtzsche PC, et al; Cochrane Bias Methods Group; Cochrane Statistical Methods Group. The cochrane collaboration's tool for assessing risk of bias in randomised trials. BMJ. 2011;343:d5928.

7. Wells GA, Shea B, O'Connell D, et al. The Newcastle-Ottawa Scale (NOS) for assessing the quality if nonrandomized studies in meta-analyses; 2009. Available from: http://www.ohri.ca/programs/ clinical_epidemiology/oxford.htm. Accessed Jauary 25, 2017.

8. Llaguna OH, Kim HJ, Deal AM, Calvo BF, Stitzenberg KB, Meyers MO. Utilization and morbidity associated with placement of a feeding jejunostomy at the time of gastroesophageal resection. $J$ Gastrointest Surg. 2011;15(10):1663-1669.

9. Heneghan HM, Zaborowski A, Fanning M, et al. Prospective study of malabsorption and malnutrition after esophageal and gastric cancer surgery. Ann Surg. 2015;262(5):803-807.

10. Carey S, Laws R, Ferrie S, Young J, Allman-Farinelli M. Struggling with food and eating - life after major upper gastrointestinal surgery. Support Care Cancer. 2013;21(10):2749-2757.

11. Greene CL, DeMeester SR, Worrell SG, Oh DS, Hagen JA, DeMeester TR. Alimentary satisfaction, gastrointestinal symptoms, and quality of life 10 or more years after esophagectomy with gastric pull-up. JThorac Cardiovasc Surg. 2014;147(3):909-914.

12. Barlow R, Price P, Reid TD, et al. Prospective multicentre randomised controlled trial of early enteral nutrition for patients undergoing major upper gastrointestinal surgical resection. Clin Nutr. 2011;30(5):560-566. 
13. Seike J, Tangoku A, Yuasa Y, Okitsu H, Kawakami Y, Sumitomo M. The effect of nutritional support on the immune function in the acute postoperative period after esophageal cancer surgery: total parenteral nutrition versus enteral nutrition. $J$ Med Invest. 2011;58(1-2):75-80.

14. Huddy JR, Macharg FMS, Lawn AM, Preston SR. Exocrine pancreatic insufficiency following esophagectomy. Dis Esophagus. 2013; 26(6):594-597.

15. Sun HB, Liu XB, Zhang RX, et al. Early oral feeding following thoracolaparoscopic oesophagectomy for oesophageal cancer. Eur $J$ Cardiothorac Surg. 2015;47(2):227-233.

16. Wang G, Chen H, Liu J, Ma Y, Jia H. A comparison of postoperative early enteral nutrition with delayed enteral nutrition in patients with esophageal cancer. Nutrients. 2015;7(6):4308-4317.

17. Kobayashi K, Koyama Y, Kosugi S, et al. Is early enteral nutrition better for postoperative course in esophageal cancer patients? Nutrients. 2013;5(9):3461-3469.

18. Tomaszek SC, Cassivi SD, Allen MS, et al. An alternative postoperative pathway reduces length of hospitalisation following oesophagectomy. Eur J Cardiothorac Surg. 2010;37(4):807-813.

19. Bowrey DJ, Baker M, Halliday V, et al. A randomised controlled trial of six weeks of home enteral nutrition versus standard care after oesophagectomy or total gastrectomy for cancer: report on a pilot and feasibility study. Trials. 2015;16:531.

20. Page RD, Oo AY, Russell GN, Pennefather SH. Intravenous hydration versus naso-jejunal enteral feeding after esophagectomy: a randomised study. Eur J Cardiothorac Surg. 2002;22(5):666-672.

21. Watters JM, Kirkpatrick SM, Norris SB, Shamji FM, Wells GA. Immediate postoperative enteral feeding results in impaired respiratory mechanics and decreased mobility. Ann Surg. 1997;226(3):369-377.

22. Xiao-Bo Y, Qiang L, Xiong Q, et al. Efficacy of early postoperative enteral nutrition in supporting patients after esophagectomy. Minerva Chir. 2014;69(1):37-46.

23. Fujita T, Daiko H, Nishimura M. Early enteral nutrition reduces the rate of life-threatening complications after thoracic esophagectomy in patients with esophageal cancer. Eur Surg Res. 2012;48(2):79-84.

24. Cooper SC, Hulley CM, Grimley CE, et al. Perioperative peripheral parenteral nutrition for patients undergoing esophagectomy for cancer: a pilot study of safety, surgical, and nutritional outcomes. Int Surg. 2006;91(6):358-364.

25. Gabor S, Renner H, Matzi V, et al. Early enteral feeding compared with parenteral nutrition after oesophageal or oesophagogastric resection and reconstruction. Br J Nutr. 2005;93(4):509-513.

26. Shiraishi T, Kawahara K, Yamamoto S, Maekawa T, Shirakusa T. Postoperative nutritional management after esophagectomy: is TPN the standard of nutritional care? Int Surg. 2005;90(1):30-35.

27. Aiko S, Yoshizumi Y, Sugiura Y, et al. Beneficial effects of immediate enteral nutrition after esophageal cancer surgery. Surg Today. 2001;31(11):971-978.

28. Baigrie RJ, Devitt PG, Watkin DS. Enteral versus parenteral nutrition after oesophagogastric surgery: a prospective randomized comparison. Aust N Z J Surg. 1996;66(10):668-670.

29. Oya H, Koike M, Iwata N, et al. Feeding duodenostomy decreases the incidence of mechanical obstruction after radical esophageal cancer surgery. World J Surg. 2015;39(5):1105-1110.

30. Huang K, Wu B, Ding X, Xu Z, Tang H. Post-esophagectomy tube feeding: a retrospective comparison of jejunostomy and a novel gastrostomy feeding approach. PLoS One. 2014;9(3):e89190.

31. Han-Geurts IJ, Hop WC, Verhoef C, Tran KT, Tilanus HW. Randomized clinical trial comparing feeding jejunostomy with nasoduodenal tube placement in patients undergoing oesophagectomy. Br J Surg. 2007;94(1):31-35.

32. Srinathan SK, Hamin T, Walter S, Tan AL, Unruh HW, Guyatt G. Jejunostomy tube feeding in patients undergoing esophagectomy. Can J Surg. 2013;56(6):409-414.

33. Fenton JR, Bergeron EJ, Coello M, Welsh RJ, Chmielewski GW. Feeding jejunostomy tubes placed during esophagectomy: are they necessary? Ann Thorac Surg. 2011;92(2):504-511; discussion 511-512.
34. Wani ML, Ahangar AG, Lone GN, et al. Feeding jejunostomy: does the benefit overweight the risk (a retrospective study from a single centre). Int J Surg. 2010;8(5):387-390.

35. Gupta V. Benefits versus risks: a prospective audit. Feeding jejunostomy during oesophagectomy. World J Surg. 2009;33(7):1432-1438.

36. Ryan AM, Rowley SP, Healy LA, Flood PM, Ravi N, Reynolds JV. Post-oesophagectomy early enteral nutrition via a needle catheter jejunostomy: 8-year experience at a specialist unit. Clin Nutrition. 2006; 25(3):386-393.

37. Sica GS, Sujendran V, Wheeler J, Soin B, Maynard N. Needle catheter jejunostomy at esophagectomy for cancer. J Surg Oncol. 2005; 91(4):276-279.

38. Yagi M, Hashimoto T, Nezuka H, et al. Complications associated with enteral nutrition using catheter jejunostomy after esophagectomy. Surg Today. 1999;29(3):214-218.

39. McCarter MD, Gomez ME, Daly JM. Early postoperative enteral feeding following major upper gastrointestinal surgery. $J$ Gastrointest Surg. 1997;1(3):278-285.

40. Wakefield SE, Mansell NJ, Baigrie RJ, Dowling BL. Use of a feeding jejunostomy after oesophagogastric surgery. Br J Surg. 1995;82(6): 811-813.

41. Gerndt SJ, Orringer MB. Tube jejunostomy as an adjunct to esophagectomy. Surgery. 1994;115(2):164-169.

42. Deldycke A, Van Daele E, Ceelen W, Van Nieuwenhove Y, Pattyn P. Functional outcome after Ivor Lewis esophagectomy for cancer. J Surg Oncol. 2016;113(1):24-28.

43. Carey S, Storey D, Biankin AV, Martin D, Young J, Allman-Farinelli M. Long term nutritional status and quality of life following major upper gastrointestinal surgery - a cross-sectional study. Clin Nutr. 2011;30(6):774-779.

44. Wang H, Tan L, Feng M, Zhang Y, Wang Q. Comparison of the shortterm health-related quality of life in patients with esophageal cancer with different routes of gastric tube reconstruction after minimally invasive esophagectomy. Qual Life Res. 2011;20(2):179-189.

45. Djarv T, Blazeby JM, Lagergren P. Predictors of postoperative quality of life after esophagectomy for cancer. J Clin Oncol. 2010;27(12): 1963-1968.

46. Parameswaran R, Blazeby J, Hughes R, Mitchell K, Berrisford R, Wajed S. Health-related quality of life after minimally invasive oesophagectomy. Br J Surg. 2010;97(4):525-531.

47. Aghajanzadeh M, Safarpour F, Koohsari MR, Ghanaei FM, Bodaghi SM, Tozandehgani H. Functional outcome of gastrointestinal tract and quality of life after esophageal reconstruction of esophagus cancer. Saudi J Gastroenterol. 2009;15(1):24-28.

48. Martin L, Lagergren J, Lindblad M, Rouvelas I, Lagergren P. Malnutrition after oesophageal cancer surgery in Sweden. Br J Surg. 2007;94(12): $1496-1500$.

49. Viklund P, Wengström Y, Rouvelas I, Lindblad M, Lagergren J. Quality of life and persisting symptoms after oesophageal cancer surgery. Eur J Cancer. 2006;42(10):1407-1414.

50. Ludwig DJ, Thirlby RC, Low DE. A prospective evaluation of dietary status and symptoms after near-total esophagectomy without gastric emptying procedure. Am J Surg. 2001;181(5):454-458.

51. McLarty AJ, Deschamps C, Trastek VF, Allen MS, Pairolero PC, Harmsen WS. Esophageal resection for cancer of the esophagus: long-term function and quality of life. Ann Thorac Surg. 1997;63(6): $1568-1572$.

52. Finley RJ, Lamy A, Clifton J, Evans KG, Fradet G, Nelems B. Gastrointestinal function following esophagectomy for malignancy. Am J Surg. 1995;169(5):471-475.

53. Ginex $P$, Thom B, Jingeleski $M$, et al. Patterns of symptoms following surgery for esophageal cancer. Oncol Nurs Forum. 2013;40(3):E101-E107.

54. Baker ML, Halliday V, Thomas A, Williams R, Bowrey D. SU1752 in hospital nutritional intake in patients undergoing elective esophagogastric resection. Gastroenterology. 2014;148(4):S-1139.

55. Martin L, Lagergren P. Long-term weight change after oesophageal cancer surgery. Br J Surg. 2009;96(11):1308-1314. 
56. Halliday V, Baker M, Thomas AL, Bowrey D. Patient and family caregivers' experiences of living with a jejunostomy feeding tube after surgery for esophagogastric cancer. JPEN J Parenter Enteral Nutr. 2015; pii:0148607115604114.

57. Johansson J, Oberg S, Wenner J, et al. Impact of proton pump inhibitors on benign anastomotic stricture formations after esophagectomy and gastric tube reconstruction: results from a randomized clinical trial. Ann Surg. 2009;250(5):667-673.
58. Blazeby JM, Conroy T, Hammerlid E, et al. Clinical and psychometric validation of an EORTC questionnaire module, the EORTC QLQOES18, to assess quality of life in patients with oesophageal cancer. Eur J Cancer. 2003;39:1384-1394.

59. Aaronson NK, Ahmedzai S, Bergman B, et al. The European Organisation for research and treatment of cancer QLQ-C30: a quality of life instrument for use in international clinical trials in oncology. $J$ Nat Cancer Instit. 1993;85(5):365-376.
Nutrition and Dietary Supplements

\section{Publish your work in this journal}

Nutrition and Dietary Supplements is an international, peer-reviewed, open access journal focusing on research into nutritional requirements in health and disease, impact on metabolism and the identification and optimal use of dietary strategies and supplements necessary for normal growth and development. The journal welcomes submitted papers covering original research, basic science,

\section{Dovepress}

clinical \& epidemiological studies, reviews and evaluations, guidelines, expert opinion and commentary, case reports and extended reports. The manuscript management system is completely online and includes a very quick and fair peer-review system, which is all easy to use. Visit http://www.dovepress.com/ testimonials.php to read real quotes from published authors. 